\title{
Parasitic fauna of eight species of ornamental freshwater fish species from the middle Negro River in the Brazilian Amazon Region
}

Fauna parasitária de oito espécies de peixes ornamentais de água doce do médio Rio Negro na Amazônia brasileira

Marcos Tavares-Dias ${ }^{1 *}$; Jefferson Raphael Gonzaga Lemos²; Maurício Laterça Martins ${ }^{3}$

${ }^{1}$ Laboratório de Aquicultura e Pesca, Empresa Brasileira de Pesquisa Agropecuária - EMBRAPA-Amapá

${ }^{2}$ Programa de Pós-graduação em Diversidade Biológica, Instituto de Ciências Biológicas, Universidade Federal do Amazonas - UFAM

${ }^{3}$ Laboratório de Sanidade de Organismos Aquáticos, Departamento de Aquicultura, Universidade Federal de Santa Catarina - UFSC

Received December 15, 2009

Accepted May 5, 2010

\begin{abstract}
Twenty-seven specimens of cardinal tetra Paracheirodon axelrodi, 33 rosy tetra Hyphessobrycon copelandi (Characidae), 28 marbled hatchetfish Carnegiella strigata, 26 blackwing hatchetfish Carnegiella martae (Gasteropelecidae), 27 bodó Ancistrus hoplogenys (Loricariidae), 31 brown pencilfish Nannostomus eques, 38 oneline pencilfish Nannostomus unifasciatus (Lebiasinidae) and 13 angelfish Pterophyllum scalare (Cichlidae) were collected from the middle Negro River, State of Amazonas, Brazil, for parasitological studies. Out of the total of 223 fish examined, 143 (64.1\%) were parasitized by at least one parasite species. The highest prevalence rate was for Monogenea (36.7\%), followed by Ichthyophthirius multifiliis (Ciliophora) (20.6\%), Trichodina spp. (Ciliophora) (4.0\%), Piscinoodinium pillulare (Dinoflagellida) (1.3\%), Tetrahymena sp. (Ciliophora) (0.89\%), and Procamallanus sp. (Nematoda) (0.4\%). All eight fish species had Monogenea (Gyrodactylidae and Dactylogyridae) in the gills, but the highest prevalence occurred in $P$. scalare and the lowest in $P$. axelrodi and $C$. strigata. However, the highest mean intensity of Monogenea was found in $P$. scalare and $A$. hoplogenys. The protozoan I. multifiliis occurred in the six ornamental fish species examined, but C. strigata and C. martae had higher prevalence and mean intensity. Trichodina spp. were found only in the gills of C. strigata, C. martae and N. eques, and with higher mean intensity in C. strigata. On the other hand, the protozoan $P$. pilullare was found only in the gills of $C$. martae. This is the first report of Tetrahymena sp. in Brazil, and it occurred in the gills of $C$. strigata.
\end{abstract}

Keywords: Infection, Monogenea, parasites, prevalence, sanity.

\section{Resumo}

Para estudos parasitológicos, 27 espécimes de cardinal Paracheirodon axelrodi, 33 rosa-céu Hyphessobrycon copelandi (Characidae), 28 peixes borboleta Carnegiella strigata e 26 Carnegiella martae (Gasteropelecidae), 27 bodó ou cascudo Ancistrus hoplogenys (Loricariidae), 31 peixes-lápis Nannostomus eques e 38 Nannostomus unifasciatus (Lebiasinidae) e 13 acará-bandeira Pterophyllum scalare (Cichlidae) foram coletados no médio Rio Negro, estado do Amazonas, Brasil. Em um total de 223 peixes examinados, $143(64,1 \%)$ estavam parasitados por pelo menos uma espécie de parasito. A maior taxa de prevalência foi de Monogenea (36,7\%), seguida de Ichthyophthirius multifiliis (Ciliophora) (20,6\%), Trichodina spp. (Ciliophora) (4,0\%), Piscinoodinium pillulare (Dinoflagellida) (1,3\%), Tetrahymena sp. (Ciliophora) $(0,89 \%)$ e Procamallanus sp. (Nematoda) $(0,4 \%)$. Todas as oito espécies de peixes mostraram Monogenea (Gyrodactylidae and Dactylogyridae) nas brânquias, mas a maior prevalência ocorreu em $P$. scalare e menor em $P$. axelrodi e C. strigata. Porém, maior intensidade média de Monogenea foi encontrada em P. scalare e A. hoplogenys. O protozoário I. multifiliis ocorreu nas seis espécies de peixes ornamentais examinadas, porém $C$. strigata e $C$. martae tiveram a maior prevalência e intensidade média. Trichodina spp. foram encontradas somente nas brânquias de C. strigata, C. martae e N. eques, mas a maior intensidade média foi em $C$. strigata. Por outro lado, o protozoário $P$. pilullare foi encontrado somente nas brânquias de C. martae. No Brasil, este é o primeiro relato de Tetrahymena sp. e ocorreu nas brânquias de C. strigata.

Palavras-chave: Infecção, Monogenea, parasitos, prevalência, sanidade. 


\section{Introduction}

Increasing demand for ornamental fish from aquarists in the United States of America, United Kingdom, Japan, Germany, Italy and Belgium has been responsible for the development of the hobby of ornamental fish keeping. Over the last ten years, the overall value of exports of ornamental fish has averaged nearly US\$ 183 million/year (PRANG, 2007). However, out of the total production of ornamental fish, only $10 \%$ are wild fish, and the State of Amazonas State contributes 64\% of such exported production. Ornamental fish species are selected on the basis of a demand for highly colorful fish that must be kept fed when in aquariums, and this last point is the key to choosing imported fish species (TAVARES-DIAS et al., 2009).

The Municipality of Barcelos, in the basin of the middle Negro River, is the largest area of ornamental fish capture in the State of Amazonas (CHAO et al., 2001). It exports 28 million fish/year, which generates an income of about US\$ 6 million/year (TAVARES-DIAS et al., 2009). From August to February, the 'igapó' forest and water from small streams ('igarapés') are strongly influenced by the flood season, which leads to higher capture rates for highly colorful ornamental fish species (FERRAZ, 1999; TAVARES-DIAS et al., 2009). At this time, fish are collected and placed on the market at the exportation holding facilities located in Manaus, Amazonas State, and subsequently exported to Germany, Netherlands, France, Belgium, UK and USA (PRANG, 2007). This exploitation of ornamental fish is an important economic resource for the local community and exporters in the State of Amazonas.

Infection caused by Piscinoodinium pilullare, in Brochis splendens and Corydoras sp. exported from the State of Amazonas to England, has occurred when fishes were kept by exporters in Brazil (FERRAZ; SOMMERVILLE, 1998). The presence of Chilodonella sp., Trichodina sp., P. pilullare, Monogenea, Nematoda and Digenean has been reported in Paracheirodon axelrodi, Symphysodon discus, Hyphessobrycon erythrostigma, Ancistrus dolichopterus, Ancistrus sp., Corydoras robinae, C. burguesi and C. adolfo $i$ from the middle Negro River, before sending the fish to the exporter in Manaus (FERRAZ, 1999). However, these fish are kept for seven to ten days in the field before being placed on the market for exportation, and under inadequate food conditions and water quality (TAVARES-DIAS et al., 2009). This may have created a favorable environment for parasite reproduction. In Dianema urostriatum, Hyphessobrycon copelandi, Otocinclus sp., Apistogramma sp. and P. axelrodi at the exporter's holding facilities in Manaus, the parasite prevalence was found to be $60.5 \%$, with the presence of Ichthyophthirius multifliis (5.5\%), Trichodina sp. (2.7\%), Henneguya sp. (0.4\%), Piscinoodinium pilullare (2.3\%), Monogenea (32.1\%), Nematoda adults $(21.1 \%)$ and larvae $(8.2 \%)$, Digenea adults $(4.6 \%)$ and metacercariae $(1.4 \%)$ and leeches Placobdella sp (0.4\%) (TAVARES-DIAS et al., 2009).

The challenge for the aquarium industry is to be able to export large quantities of good-quality fish (TAVARES-DIAS et al., 2009). Parasites imported with ornamental fish may present risks, both to native fish populations and to the aquaculture industry. The introduction of a new parasite may have devastating effects on native fish species, as these may not have evolved appropriate defense mechanisms against foreign organisms. However, no study has been carried out regarding infection rates among ornamental fish from the middle Negro River basin.

This study was designed to investigate the parasitic fauna of eight ornamental fish species that were collected from the middle Negro River, Municipality of Barcelos, State of Amazonas. This location accounts for most of the species from the Brazilian Amazonia that are captured and placed on the market.

\section{Material and Methods}

This trial was carried out in November 2005. At that time, specimens of Paracheirodon axelrodi Schultz, 1956 (Characidae); Carnegiella strigata Günther, 1864; Carnegiella martae Myers, 1927 (Gasteropelecidae); Ancistrus hoplogenys Günther, 1864 (Loricariidae); Hyphessobrycon copelandi Durbin, 1908 (Characidae); Nannostomus eques Steindachner, 1876; Nannostomus unifasciatus Steindachner, 1876 (Lebiasinidae) and Pterophyllum scalare Schultze, 1823 (Cichlidae) were collected by netting from a black water tributary (Igarapé Puxirituba: 00 54' 168" S and $\left.62^{\circ} 42^{\prime} 672^{\prime} \mathrm{W}\right)$ in the middle Negro River basin, municipality of Barcelos, State of Amazonas, Brazil, and were identified (CHAO et al., 2001) for parasitological examination. After sacrifice, the fish were necropsied for parasitological examination (GHIRALDELLI et al., 2007). The parasites were processed (EIRAS; TAKEMOTO; PAVANELLI, 2000; MARTINS, 2007) and counted (TAVARES-DIAS; MARTINS; MORAES, 2001a). They were identified in accordance with Thatcher (2006), and the prevalence and mean intensity were calculated in accordance with Bush et al. (1997).

During fish collection, the physical-chemical parameters of the water were measured. The hydrogen potential $(\mathrm{pH})$ was determined using digital equipment ( $\mathrm{pH}$-meter WTW - D812 model), and the temperature, electric conductivity and dissolved oxygen were also determined using digital equipment (YSI-Model-55). The $\mathrm{pH}$ ranged from 1.5 to 2.7 , temperature from 27.0 to 29.1 , electric conductivity from 10.8 to $41.5 \mu \mathrm{S} . \mathrm{cm}^{-1}$ and dissolved oxygen 1.2 to $2.9 \mathrm{mg} . \mathrm{L}^{-1}$.

\section{Results}

Among the 223 fish examined, 143 (64.1\%) were parasitized by at least one parasite species, and a total of 1,765 parasites were collected. The highest prevalence among the fish studied was of Monogenea Gyrodactylidae and Dactylogyridae (36.7\%), followed by Ichthyophthirius multifliis Fouquet, 1876 (Ciliophora) (20.6\%), Trichodina spp. (Ciliophora) (4.0\%), P. pillulare (Dinoflagellida) (1.3\%), Tetrahymena Furgason, 1940 (Ciliophora) (0.89\%) and Procamallanus Baylis, 1923 (0.4\%) (Table 1).

Ichthyophthirius multifiliis was found in six fish species, but $C$. strigata and $C$. martae showed the highest prevalence and mean intensity. Trichodina spp. was only observed in C. strigata, C. martae and $N$. eques, but with higher mean intensity in $C$. strigata (13.5), ranging from 2 to 45 parasites per host. Piscinoodinium pilullare was found in $C$. martae with $7.8 \%$ prevalence and mean intensity of $2.7 \pm 1.6$. Tretahymena sp. was found in $7.1 \%$ of $C$. strigata examined with a mean intensity of $2.5 \pm 0.5$. Procamallanus species was found only in the intestine of one specimen of $P$. axelrodi (Table 2). 
Unidentified Monogenea species were found in the gills of all the fish species, but the highest prevalence occurred in $P$. scalare (92.3\%) and the lowest in $P$. axelrodi $(7.4 \%)$ and C. strigata (7.1\%). On the other hand, the highest mean intensities were found in P. scalare (12.2\%) and A. hoplogenys (11.4\%) (Table 2). Monogenea species of the genus Gyrodactylus Nordman, 1832 (Gyrodactylidae) were found in the gills of P. axelrodi, C. strigata and C. martae; Dactylogyrus Diesing, 1851 (Dactylogyridae) in $N$. eques and N. unifasciatus; Nothogyrodactylus Kritsky and Boeger, 1991 (Gyrodactylidae) in A. hoplogenys; Urocleidoides Mizelle and Price, 1964 (Dactylogyridae) in H. copelandi and Gussevia Kohn and Paperna, 1964 (Dactylogyridae) in P. scalare.

\section{Discussion}

The ornamental fish from the Negro River basin of the Brazilian Amazon region that were examined in the present survey presented greater parasitism $(64.1 \%)$ than did those examined by Piazza et al. (2006) in Florianópolis, Southern Brazil (34.0\%). However, Piazza et al. (2006) studied fish species that were different from those examined in the present study. On the other hand, the prevalence of parasitism in the present study was similar to what was reported for ornamental fish species at an exporter's holding facility in Manaus, in the State of Amazonas (TAVARES-DIAS et al., 2009). Because of the social and economic importance of the ornamental fish industry, it is necessary to improve capture practices, from the stage of handling and maintenance of fish in the field, to their dispatch by exporters (FERRAZ, 1999).
For eight species of ornamental fish from the middle Negro River basin, State of Amazonas, Monogenea species were the most common parasites, followed by I. multifliis. However, C. strigata, $C$. martae and $H$. copelandi presented the highest infection rates caused by $I$. multifiliis, while $P$. axelrodi and $C$. strigata had the lowest infection rates caused by Monogenea. Similarly, Ferraz (1999) reported that Monogenea and I. multifiliis were the most common parasites in the same region as our study. However, Ferraz (1999) reported myxosporean parasites in the skin and gills of ornamental fish; they were not observed in our study. High prevalence of Monogenea species and I. multifiliis were also reported by Carnevia and Speranza (2003), in ornamental fish reared in Uruguay, Colombia and Peru. Furthermore, in a survey on parasitic diseases of freshwater ornamental fishes placed on the market in Florianópolis, Santa Catarina, Monogenean species and digenean metacercariae of Ascocotyle sp. were the parasites most frequent found (PIAZZA et al., 2006).

In southeastern Brazil, Monogenea species and I. multifiliis have been the most common parasites found in cultivated fish (TAVARES-DIAS; MARTINS; MORAES, 2001a). Our results showed that both of these parasites are widespread and well adapted to different environmental conditions. In addition, I. multifliis is a protozoan of low host specificity and its life cycle depends on the water temperature (GHIRALDELLI et al., 2007; LEMOS et al., 2007). Moreover, Monogenea has high host specificity. Gyrodactylids are viviparous and dactylogyrids are oviparous, but have a monoxenic life cycle that makes it more likely that they will become infected under propitious environmental conditions (THILAKARATNE et al., 2003; THATCHER, 2006).

Table 1. Parasites of eight ornamental freshwater fishes from the middle Negro River, municipality of Barcelos, Amazonas State (Brazil), in November 2005.

\begin{tabular}{ccccc}
\hline Parasites & PF/EF & Prevalence (\%) & TNP & MI \pm SD (range) \\
\hline Ichthyophthirius multifiliis & $46 / 223$ & 20.6 & 1148 & $24.9 \pm 17.4(1-65)$ \\
Trichodina spp. & $9 / 223$ & 4.0 & 76 & $8.4 \pm 13.1(2-45)$ \\
Piscinoodinium pilullare & $3 / 223$ & 1.3 & 9 & $2.7 \pm 1.6(1-5)$ \\
Tetrahymena sp. & $2 / 223$ & 0.89 & 5 & $2.5 \pm 0.5(2-3)$ \\
Monogenea & $82 / 223$ & 36.7 & 526 & $6.4 \pm 4.3(2-23)$ \\
Procamallanus sp. & $1 / 223$ & 0.4 & 1 & 1 \\
\hline Total & $143 / 223$ & 64.1 & 1765 & $12.3 \pm 14.0(1-65)$ \\
\hline
\end{tabular}

PF/EF: parasitized fish/examined fish; TNP: total number of parasites; the mean intensity (MI) is followed by standard deviation (SD) and range between parentheses.

Table 2. Parasitological indexes of Ichthyophthirius multifliis, Trichodina spp. and Monogenea in the gills of eight ornamental freshwater fish from the middle Negro River, municipality of Barcelos, State of Amazonas (Brazil), in November 2005.

\begin{tabular}{|c|c|c|c|c|c|c|c|}
\hline \multicolumn{2}{|l|}{ Parasites } & \multicolumn{2}{|c|}{ Ichthyophthirius multifiliis } & \multicolumn{2}{|c|}{ Trichodina spp. } & \multicolumn{2}{|c|}{ Monogenea } \\
\hline Hosts & EF & $\mathbf{P}(\%)$ & $\mathrm{MI} \pm \mathrm{SD}$ (range) & $\mathbf{P}(\%)$ & $\mathrm{MI} \pm \mathrm{SD}$ (range) & $\mathbf{P}(\%)$ & $\mathrm{MI} \pm \mathrm{SD}$ (range) \\
\hline Paracheirodon axelrodi & 27 & 0 & 0 & 0 & 0 & 7.4 & $2.5 \pm 0.5(2-3)$ \\
\hline Carnegiella strigata & 28 & 64.3 & $33.2 \pm 16.8(3-65)$ & 14.3 & $13.5 \pm 18.2(2-45)$ & 7.1 & $6.5 \pm 3.5(3-10)$ \\
\hline Carnegiella martae & 26 & 53.8 & $30.0 \pm 15.2(16-60)$ & 7.9 & $6.5 \pm 3.5(3-10)$ & 65.4 & $4.8 \pm 2.7(2-10)$ \\
\hline Ancistrus hoplogenys & 27 & 0 & 0 & 0 & 0 & 29.6 & $11.4 \pm 1.2(10-13)$ \\
\hline Hyphessobrycon copelandi & 33 & 21.2 & $11.4 \pm 6.8(3-20)$ & 0 & 0 & 21.2 & $9.6 \pm 1.5(6-10)$ \\
\hline Nannostomus eques & 31 & 6.4 & $2.5 \pm 0.5(2-3)$ & 9.7 & $3.3 \pm 0.8(2-4)$ & 48.4 & $4.5 \pm 2.5(2-10)$ \\
\hline Nannostomus unifasciatus & 38 & 7.9 & $8.0 \pm 8.5(1-20)$ & 0 & 0 & 47.4 & $2.8 \pm 1.1(2-5)$ \\
\hline Pterophyllum scalare & 13 & 23.1 & $11.0 \pm 1.0(10-12)$ & 0 & 0 & 92.3 & $12.2 \pm 4.2(10-23)$ \\
\hline
\end{tabular}

EF: examined fish; P (\%): Prevalence; MI: mean intensity, followed by standard deviation (SD) and range in parentheses. 
The monogenean species Gyrodactylus sp. has been found parasitizing the gills of $P$. axelrodi, $C$. strigata and $C$. martae; Dactylogyrus sp., parasitizing the gills of $N$. eques and $N$. unifasciatus; Nothogyrodactylus, parasitizing the gills of $A$. hoplogenys; Urocleidoides sp., parasitizing the gills of $H$. copelandi; and Gussevia sp., parasitizing the gills of $P$. scalare. Similarly, Gussevia species have also been reported parasitizing Astronotus ocellatus and P. scalare; Gyrodactylus species parasitizing Corydoras paleatus and C. ehrhardti; Nothogyrodactylus species parasitizing Ancistrus sp.; and Urocleidoides species parasitizing $C$. aeneus (THATCHER, 2006), in different localities in the Brazilian Amazon region.

The protozoan $P$. pilullare was found only in the gills of C. martae, while Tretahymena sp. infected only the gills of C. strigata, in specimens from the Negro River. However, both parasites had low infection rates. Infection due to Tetrahymena species (KIM et al., 2002; LEIBOWITZ; ARIAV; ZILBERG, 2005) and $P$. pilullare (THILAKARATNE et al., 2003; PIAZZA et al., 2006) are influenced by poor water quality and high content of organic matter. Many tropical and temperate-region fish are susceptible to $P$. pilullare, because this parasite is nonspecific. This was the first report of ciliates of the genus Tetrabymena in Brazilian fish species. Tetrahymena are free-living species that consume organic matter and bacteria in natural habitats, but they infect fish that are stressed by adverse environmental conditions (LEIBOWITZ; ARIAV; ZILBERG, 2005). This genus of ciliates is commonly known as the 'guppy-killer parasite' (KIM et al., 2002; LEIBOWITZ; ARIAV; ZILBERG, 2005), and its geographical distribution is not limited to North America, Europe, Asia and Africa, as demonstrated here.

Trichodinids were found only in the gills of C. strigata, C. martae and $N$. eques, and the highest mean intensity was in $C$. strigata. In addition, $P$. axelrodi, $A$. hoplogenis, $H$. copelandi, $N$. unifasciatus and $P$. scalare were the fishes that were most resistant to trichodinids. However, one point that must be highlighted is the difference in fish susceptibility or innate immunity that may occur, depending on the fish species. In this study, the degree of parasitism due to trichodinids was similar to what has been reported for Xiphophorus maculatus, cultured in southern Brazil (PIAZZA et al., 2006) and Hyphessobrycon sp., cultured in Sri Lanka (THILAKARATNE et al., 2003). Therefore, knowledge of ornamental fish health is important for avoiding diseases.

In this study, low prevalence and mean intensity of nematode infection were poorly observed in $P$. axelrodi. Presence of Procamallanus sp. may sometimes cause perforation of the pyloric cecum, intestinal obstruction and hemorrhages (FERRAZ, 1999). Fishermen of the Amazonian region have reported that it is common to observe fish with a swollen abdomen, possibly because of the presence of nematodes. Several species of nematodes in the genus Procamallanus (Camallanidae) are commonly found in neotropical fish (MORAVEC; WOLTER; KÖRTING, 1999; THATCHER, 2006). Some of them may cause host death because of the way in which they become attached to the intestinal epithelium (FERRAZ, 1999; THATCHER, 2006). Camallanid nematode species generally use a copepod as an intermediate host, as noted by Moravec, Wolter e Korting (1999) and demonstrated by Martins et al. (2007) in a study on experimental infection of Notodiaptomus sp. with Camallanus maculatus.
In conclusion, $P$. axelrodi, $A$. hoplogenis and $P$. scalare were the fish species that were most resistant to parasites in the middle Negro River. However, high prevalence of parasites was found for other ornamental fishes that are placed on the market through exportation holding facilities in Manaus (AM). Therefore, monitoring of the health status of ornamental fish needs to be one of the most important activities in exportation holding facilities; because any ornamental fish trade operation without adequate sanity practices will lead to significant economic losses for the exporter, as well as having a negative influence on exportation. Consequently, introduction of transmissible parasites may cause serious disease outbreaks among the imported fish, thereby compromising the exportation industry.

\section{Acknowledgements}

The authors thank the National Geographic Society Conservation Foundation for an expedition grant (No. C47-04), the Research Foundation of the State of Amazonas FAPEAM) (Grant: 2203/05) and the National Council for Scientific and Technological Development (CNPq) (Grant: 350117/2005-5), and for CNPq grants to Maurício L. Martins (CNPq research fellow) and Marcos Tavares-Dias (CNPq research fellow).

The scientific expedition was authorized by the Brazilian Ministry of Science and Technology (MCT/CNPq, process No. EXC 023/05 to J.L.M.) and by the Federal Environmental Agency (process No. 098/2005 DIFAP/IBAMA-DF).

\section{References}

BUSH, A. O. et al. Parasitology meets ecology on its own terms. Journal of Parasitology, v. 83, n. 4, p. 575-583, 1997.

CARNEVIA, D.; SPERANZA, G. Enfermedades diagnosticadas em peces ornamentales tropicaleis de criaderos de Uruguay: I. Parasitosis. Veterinaria Montevideo, v. 38, n. 150-151, p. 29-34, 2003.

CHAO, N. L. et al. Conservation and management of ornamental fish resources of the Rio Negro basin, Amazonia, Brazil- Projetc Piaba. EDUA: Manaus, 2001. 301 p.

EIRAS, J. C.; TAKEMOTO, R. M.; PAVANELLI, G. C. Métodos de estudo e técnicas laboratoriais em parasitologia de peixes. Maringá: Ed. EDUEM, 2000. 171 p.

FERRAZ, E. Management and diseases of the ornamental fish exported from the Rio Negro basin. In: VAL, A. L.; ALMEIDA-VAL, V. M. (Eds). Biology of tropical fishes. INPA: Manaus, 1999. p. 99-111.

FERRAZ, E.; SOMMERVILLE, C. Pathology of Piscinoodinium sp. (Protozoa; Dinoflagellida), parasites of the ornamental freshwater catfishes Corydoras spp. and Brochis splendens (Pisces: Callichthyidae). Diseases of Aquatic Organisms, v. 33, n. 1, p. 43-49, 1998.

GHIRALDELLI, L. et al. Infecção com trofozoítos de Ichthyophthirius multifiliis (Ciliophora) em Poecilia vivipara (Poeciliidae) como hospedeiro experimental. Ciência Animal Brasileira, v. 8, n. 1, p. 105-110, 2007.

KIM, J. H. et al. Parasitic infections in live freshwater tropical fishes imported to Korea. Diseases of Aquatic Organisms, v. 52, n. 2, p. 169-173, 2002. 
LEIBOWITZ, M. P.; ARIAV, R.; ZILBERG, D. Environmental and physiological conditions affecting Tetrahymena sp. infection in guppies, Poecilia reticulata Peters. Journal of Fish Diseases, v. 28, n. 9 , p. 539-547, 2005.

MARTINS, M. L. et al. Experimental infection in Notodiaptomus sp. (Crustacea: Calanoida) with larvae of Camallanus sp. (Nematoda: Camallanidae). Arquivo Brasileiro de Medicina Veterinária e Zootecnia, v. 59, n. 2, p. 382-386, 2007.

MORAVEC, F.; WOLTER, J.; KÖRTING, W. Some nematodes and acanthocephalans from exotic ornamental freshwater fishes imported into Germany. Folia Parasitologica, v. 46, n. 4, p. 296-310, 1999.

PIAZZA, R. S. et al. Parasitic diseases of freshwater ornamental fishes commercialized in Florianópolis, Santa Catarina, Brazil. Boletim do Instituto Pesca, v. 32, n. 1, p. 51-57, 2006.

PRANG, G. An industry analysis of the freshwater ornamental fishery with particular reference to the supply of Brazilian freshwater ornamentals to the UK market. Uakari, v. 3, n. 1, p. 7-51, 2007.
TAVARES-DIAS, M. et al. Metazoan and protozoan parasites of freshwater ornamental fish from Brazil. In: TAVARES-DIAS, M. (Org.). Manejo e sanidade de peixes em cultivo. Macapá: Embrapa Amapá, 2009. p. 469-494.

TAVARES-DIAS, M.; MARTINS, M. L.; MORAES, F. R. Fauna parasitária de peixes oriundos de "pesque-pague" do município de Franca, São Paulo, Brasil. I. Protozoários. Revista Brasileira de Zoologia, v. 18, supl. 1, p. 67-79, 2001a.

TAVARES-DIAS, M. et al. Fauna parasitária de peixes oriundos de "pesque-pagues" do município de Franca, São Paulo, Brasil. II. Metazoários. Revista Brasileira de Zoologia, v. 18, supl. 1, p. 81-95, $2001 b$.

THATCHER, V. E. Amazon fish parasites. Sofia-Moscow: Pensoft Publishers, 2006.

THILAKARATNE, I. D.; et al. Parasitic infections in freshwater ornamental fish in Sri Lanka. Diseases of Aquatic Organisms, v. 54, n. 2, p. 157-162, 2003. 